\title{
Patterns of smoking in the Baltic Republics
}

Iveta Pudule, Daiga Grinberga, Kamelija Kadziauskiene, Algis Abaravicius, Sirje Vaask, Aileen Robertson, Martin McKee

\begin{abstract}
Background-Tobacco is a leading cause of avoidable death in the Baltic Republics but there is, as yet, relatively little information in the public domain on who is smoking and how this is changing. This information is important for those seeking to develop effective policies to tackle this issue.
\end{abstract}

Objective-To determine the pattern of smoking in Estonia, Latvia, and Lithuania.

Methods-Analysis of data on patterns of tobacco consumption from representative surveys of approximately 3000 adults aged under 65 in each country undertaken in 1997.

Results-The prevalence of smoking among men is $53.9 \%, 56.0 \%$, and $53.2 \%$ respectively in Estonia, Latvia, and Lithuania. The corresponding figures for women are $24.1 \%, 10.9 \%$, and $7.6 \%$. For both sexes, current smoking rates are consistently lowest in the age group 50 to 64 and highest in the age group 35 to 49 . Education and income are determinants of smoking rates among men but much less so among women. Russian men are more likely to smoke than are men from the majority group in each country. Smoking rates among women are much lower in rural than in urban areas of Latvia and Lithuania but this is not so in Estonia.

Conclusions-Smoking rates among men in the Baltic Republics are already very high. Among women, they still vary considerably. Each country has implemented some measures to reduce smoking. These seem to have been especially effective in Lithuania but, overall, much more action is needed.

(F Epidemiol Community Health 1999;53:277-282)

Department, Ministry

of Social Affairs,

Tallinn, Estonia

$S$ Vaask

WHO Regional Office for Europe,

Copenhagen, Denmark

A Robertson

European Centre on Health of Societies in Transition, London School of Hygiene and Tropical Medicine, London WC1E 7HT $\mathrm{M}$ McKee

Correspondence to: Professor McKee.

Accepted for publication 8 December 1998
An effective policy response is needed now to avert the risk of a substantial increase in the burden of disease in the $21 \mathrm{st}$ century. This requires knowledge of who is smoking and how this is changing in different countries. Although the trans-national tobacco companies have a large amount of data to aid marketing, there is little detailed information in the public domain. The most recent data on the World Health Organisation's Health for All database give only overall percentages of smokers among those aged 15 and over. ${ }^{4}$ These are, for Latvia, in $1992,49.4 \%$ of men and $11.1 \%$ women, for Estonia in $1996,47.5 \%$ in men and $21.7 \%$ in women, and for Lithuania in 1992, 30\% overall.

We describe the results from three representative surveys undertaken in each of the Baltic countries to determine the current prevalence of smoking and its relation with a range of socioeconomic factors.

\section{Methods}

Surveys were conducted in each country in June 1997. The principal focus of the surveys was on nutrition but, in addition, questions on smoking were included. These questions included current smoking, past smoking, and number of cigarettes smoked per day. Respondents were asked "Do you smoke?" with possible answers "yes, daily", "yes, occasionally", and "No". They were also asked "Have you ever smoked?" with possible responses "Yes, daily", "Yes, Occasionally", or "No". Smokers were defined as daily smokers.

The survey sought to include 3000 people that were representative of the national population aged between 19 and 64 years (20 and 64 in Lithuania). In each country, the sampling frames were the National Population Registers. All interviews were conducted in the person's own home during the summer of 1997. Interviews were conducted in both the national language and in Russian.

In Estonia, a simple random sample was drawn from the register. Interviewers did not return to a house if there was no reply and substitution was allowed if the response rate in the county in question was less than $60 \%$, which happened in seven of the 15 counties. Overall less than $5 \%$ of people were substituted. Interviews were conducted by public health specialists, nutritionists, and people with previous interviewing experience. Each attended a one day initial training session. The response rate was $67.3 \%$.

In Latvia, two stage sampling was used, with the first stage selecting a sample for each of the 26 regions of Latvia according to population size. In the second stage, a random sample 
Table 1 Characteristics of samples and countries-all figures relating to sample are percentages

\begin{tabular}{llll}
\hline Variable & \multirow{2}{*}{ Estonia } & Latvia & Lithuania \\
\hline Sample data & & & \\
Male & 44.7 & 45.9 & 45.5 \\
Female & 55.3 & 54.1 & 54.5 \\
Estonian & 69.6 & & \\
Latvian & & 54.7 & \\
Lithuanian & 24 & 34.7 & 84.3 \\
Russian & & & 5.7 \\
Polish & 6.4 & 10.6 & 1.3 \\
Other & 12.6 & 19 & 20 \\
Primary education & 45.8 & 32.4 & 25.3 \\
Secondary education & 41.5 & 48.2 & 54.1 \\
University/specialised education & 66.1 & 66.5 & 66.7 \\
Urban & 33.9 & 33.5 & 33.3 \\
Rural & & & \\
Country data & 1600 & 2700 & 3700 \\
Population ('000) & 2430 & 2270 & 1900 \\
GNP per capita (US $\$$ 1995) & 13 & 19 & 24 \\
\% Employed in agriculture & & & \\
Approximate cost of a packet of & $\$ 1.50$ & $\$ 2$ & $\$ 1$ \\
$\quad$ Malborough cigarettes (1998) & & & \\
\hline
\end{tabular}

within the strata were selected. The exception was for the city of Riga, were there seemed to be problems with the population register data, with a disproportionate number of people reg-

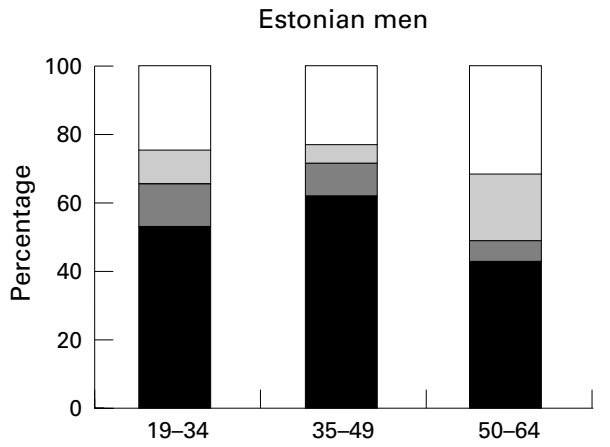

Latvian men

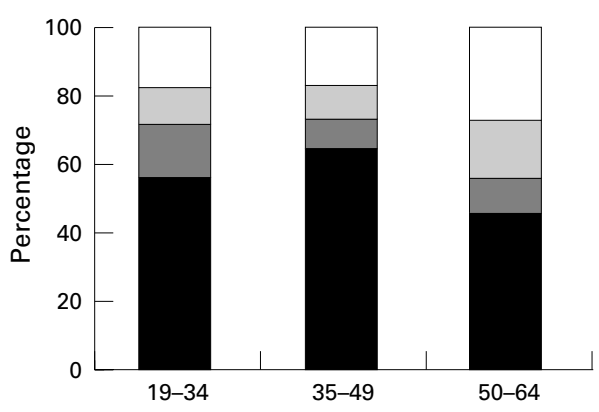

Lithuanian men
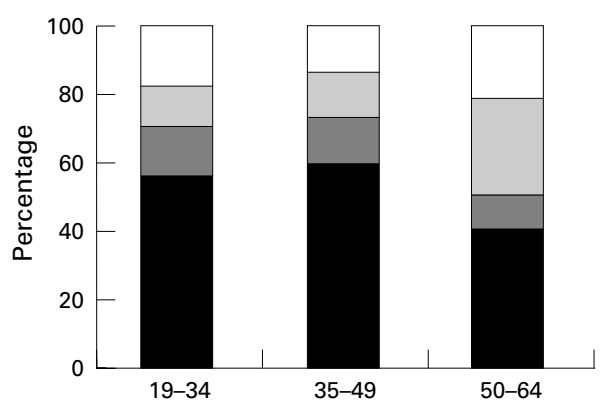

istered with ages over 60. Consequently, in Riga, the second stage sample was also stratified by age group. Interviewers were recruited from the regional environmental health centres. Substitution was not permitted and interviewers would return to an address up to five times. Each received interviewer received training. The response rate was $77.7 \%$.

In Lithuania a sample of 3000 names was drawn at random from those people listed on the National Population Register that were living at addresses in Lithuania and were aged between 20 and 65 . Interviewers were mainly assistants working in hygiene stations, who underwent an initial training session. In most cases the interviewers returned to an address on multiple occasions if they were unable to find the subject. There was no substitution. The response rate was $74.1 \%$.

Most of the variables analysed are self explanatory. The income variable relates to family income. In each country it was divided into four categories based on national criteria
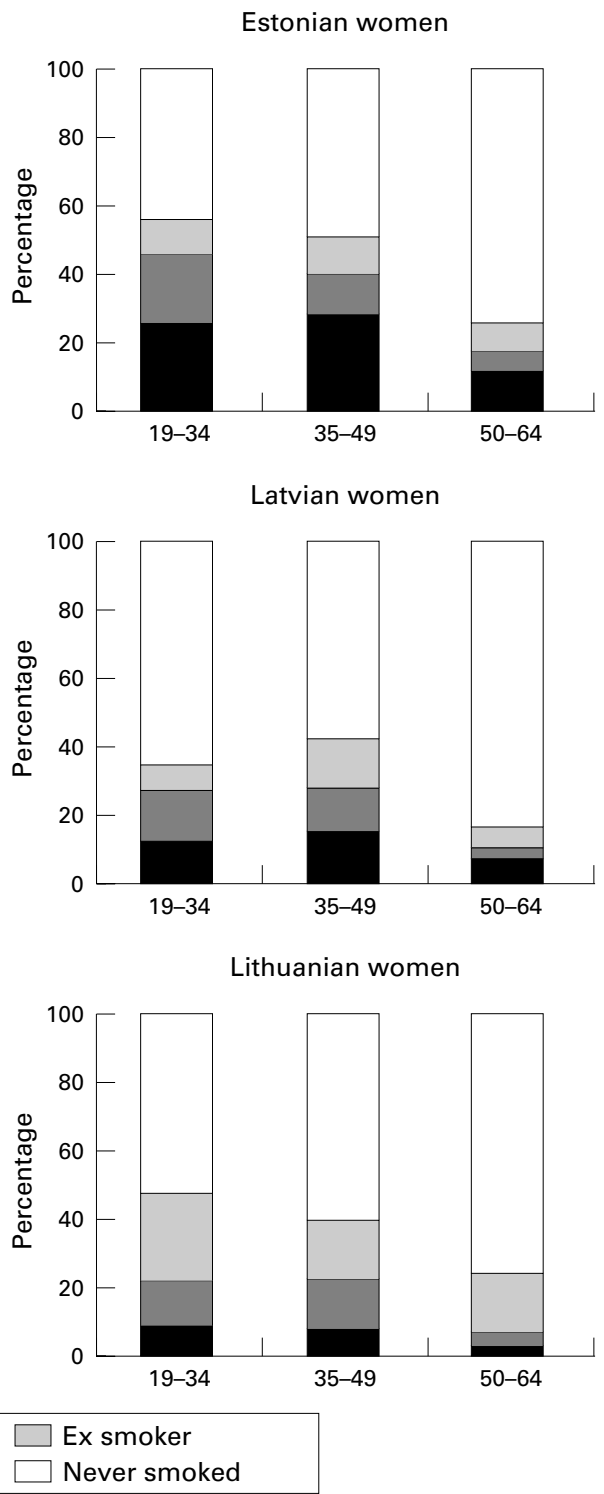

Figure 1 Smoking history by age in men and women in the Baltic countries. 
Table 2 Percentages and adjusted odds ratios (95\% confidence intervals in parentheses) for present smoking among Estonian adults by a range of socioeconomic variables

\begin{tabular}{|c|c|c|c|c|}
\hline & Category & Unadjusted rates (\%) & Age adjusted & Fully adjusted \\
\hline \multirow[t]{3}{*}{$\overline{\text { Male }}$} & Age 19-34 & $53(48,58)$ & 1.00 & 1.00 \\
\hline & Age $35-49$ & $61(56,67)$ & $1.39(1.03,1.88)$ & $1.37(0.99,1.82)$ \\
\hline & Age $50-64$ & $43(36,50)$ & $0.66(0.46,0.93)$ & $0.56(0.42,0.89)$ \\
\hline \multirow[t]{2}{*}{ Nationality } & Estonian & $53(49,56)$ & 1.00 & 1.00 \\
\hline & non-Estonian & $57(51,63)$ & $1.14(0.85,1.53)$ & $1.44(0.76,1.41)$ \\
\hline \multirow{2}{*}{ Region } & Urban & $52(48,56)$ & 1.00 & 1.00 \\
\hline & Rural & $57(52,62)$ & $1.13(0.95,1.64)$ & $0.81(0.24,5.36)$ \\
\hline \multirow{3}{*}{ Education } & Primary & $57(48,65)$ & 1.00 & 1.00 \\
\hline & Secondary & $58(53,63)$ & $0.90(0.60,1.36)$ & $0.77(0.67,1.57)$ \\
\hline & University & $48(42,53)$ & $0.61(0.40,0.92)$ & $0.74(0.47,1.14)$ \\
\hline \multirow[t]{4}{*}{ Income } & under $\$ 75$ & $63(56,69)$ & 1.00 & 1.00 \\
\hline & $\$ 74-\$ 149$ & $53(47,59)$ & $0.67(0.47,0.96)$ & $0.70(0.49,1.02)$ \\
\hline & $\$ 150-\$ 299$ & $50(43,56)$ & $0.58(0.40,0.84)$ & $0.83(0.43,0.93)$ \\
\hline & $\$ 300+$ & $49(40,58)$ & $0.52(0.33,0.82)$ & $0.42(0.38,0.98)$ \\
\hline \multirow[t]{3}{*}{ Female } & age $19-34$ & $27(23,31)$ & 1.00 & 1.00 \\
\hline & age $35-49$ & $29(24,34)$ & $1.10(0.26,1.60)$ & $1.15(0.86,1.60)$ \\
\hline & age $50-64$ & $13(9,17)$ & $0.40(0.30,0.45)$ & $0.51(0.30,0.70)$ \\
\hline \multirow{2}{*}{ Nationality } & Estonian & $24(21,27)$ & 1.00 & 1.00 \\
\hline & non-Estonian & $24(19,28)$ & $1.04(0.77,1.40)$ & $1.09(0.78,1.46)$ \\
\hline \multirow{2}{*}{ Region } & Urban & $25(22,28)$ & 1.00 & 1.00 \\
\hline & Rural & $23(18,28)$ & $0.98(0.73,1.36)$ & $0.98(0.72,1.33)$ \\
\hline \multirow[t]{3}{*}{ Education } & Primary & $13(7,19)$ & 1.00 & 1.00 \\
\hline & Secondary & $28(25,32)$ & $1.95(1.07,3.56)$ & $0.77(1.07,3.68)$ \\
\hline & University & $23(19,26)$ & $1.37(0.75,2.51)$ & $0.57(0.73,2.62)$ \\
\hline \multirow{4}{*}{ Income } & under $\$ 75$ & $23(18,27)$ & 1.00 & 1.00 \\
\hline & $\$ 74-\$ 149$ & $24(20,27)$ & $0.98(0.70,1.38)$ & $0.63(0.69,1.38)$ \\
\hline & $\$ 150-\$ 299$ & $24(19,29)$ & $0.94(0.64,1.40)$ & $1.06(0.65,1.47)$ \\
\hline & $\$ 300+$ & $36(24,47)$ & $1.52(0.86,2.69)$ & $0.98(0.86,2.76)$ \\
\hline
\end{tabular}

for the poverty level, with the poorest category considered to be living in severe poverty.

Data were analysed using tabulations and binomial logistic regression in the Statistical Package for the Social Sciences (SPSS). Confidence intervals were calculated using Excel. As age and sex were strong determinants of smoking rates, results were analysed separately for men and women and the odds ratios for being a smoker according to a range of variables were calculated, both with adjustment only for age and for all of the other variables studied. Nationality was classified as either that of the native population or "other", which essentially equates to Russian, Ukrainian or Belarussian. The exception was Lithuania, where there is a

Table 3 Percentages and adjusted odds ratios (95\% confidence intervals in parentheses) for present smoking among Latvian adults by a range of socioeconomic variables

\begin{tabular}{|c|c|c|c|c|}
\hline & Category & Unadjusted rates (\%) & Age adjusted & Fully adjusted \\
\hline \multirow[t]{3}{*}{ Male } & age $19-34$ & $56(51,62)$ & 1.00 & 1.00 \\
\hline & age $35-49$ & $65(60,70)$ & $1.45(1.07,1.97)$ & $1.37(0.99,1.89)$ \\
\hline & age $50-64$ & $46(41,51)$ & $0.67(0.49,0.90)$ & $0.56(0.40,0.78)$ \\
\hline \multirow[t]{2}{*}{ Nationality } & Latvian & $52(47,56)$ & 1.00 & 1.00 \\
\hline & non-Latvian & $62(57,66)$ & $1.47(1.14,1.88)$ & $1.44(1.09,1.90)$ \\
\hline \multirow{2}{*}{ Region } & Urban & $58(54,62)$ & 1.00 & 1.00 \\
\hline & Rural & $52(47,57)$ & $0.78(0.60,1.01)$ & $0.81(0.60,1.09)$ \\
\hline \multirow[t]{3}{*}{ Education } & Primary & $57(51,64)$ & 1.00 & 1.00 \\
\hline & Secondary & $57(52,62)$ & $0.80(0.56,1.15)$ & $0.77(0.53,1.13)$ \\
\hline & University & $55(51,59)$ & $0.73(0.52,1.03)$ & $0.74(0.51,1.07)$ \\
\hline \multirow{4}{*}{ Income } & under $\$ 50$ & $61(56,66)$ & 1.00 & 1.00 \\
\hline & $\$ 51-\$ 100$ & $53(48,57)$ & $0.75(0.56,1.00)$ & $0.70(0.52,0.96)$ \\
\hline & $\$ 101-\$ 150$ & $59(50,67)$ & $0.90(0.59,1.36)$ & $0.83(0.53,1.30)$ \\
\hline & $\$ 151+$ & $44(33,55)$ & $0.46(0.28,0.75)$ & $0.42(0.25,0.70)$ \\
\hline \multirow[t]{3}{*}{ Female } & age $19-34$ & $12(9,15)$ & 1.00 & 1.00 \\
\hline & age $35-49$ & $14(11,18)$ & $1.21(0.79,1.86)$ & $1.15(0.73,1.80)$ \\
\hline & age $50-64$ & $7(5,10)$ & $0.57(0.36,0.91)$ & $0.51(0.31,0.84)$ \\
\hline \multirow[t]{2}{*}{ Nationality } & Latvian & $9(7,12)$ & 1.00 & 1.00 \\
\hline & non-Latvian & $13(10,15)$ & $1.35(0.94,1.93)$ & $1.09(0.74,1.60)$ \\
\hline \multirow[t]{2}{*}{ Region } & Urban & $13(11,15)$ & 1.00 & 1.00 \\
\hline & Rural & $6(4,9)$ & $0.44(0.28,0.69)$ & $0.36(0.22,0.59)$ \\
\hline \multirow{3}{*}{ Education } & Primary & $12(7,16)$ & 1.00 & 1.00 \\
\hline & Secondary & $11(8,15)$ & $0.79(0.46,1.33)$ & $0.77(0.44,1.32)$ \\
\hline & University & $10(8,13)$ & $0.66(0.39,1.09)$ & $0.57(0.33,0.98)$ \\
\hline \multirow{4}{*}{ Income } & under $\$ 50$ & $12(9,15)$ & 1.00 & 1.00 \\
\hline & $\$ 51-\$ 100$ & $9(7,11)$ & $0.75(0.50,1.13)$ & $0.63(0.41,0.97)$ \\
\hline & $\$ 101-\$ 150$ & $14(8,21)$ & $1.23(0.67,2.25)$ & $1.06(0.56,2.00)$ \\
\hline & $\$ 151+$ & $14(5,23)$ & $1.17(0.53,2.61)$ & $0.98(0.42,2.27)$ \\
\hline
\end{tabular}

KEY POINTS

- Rates of smoking among men in the Baltic Republics are high, in international terms.

- Rates among women vary between the three countries, with much higher rates in Estonia than in Latvia and Lithuania.

- The rate of quitting is higher in Lithuania than in the other countries, although the factors associated with quitting remain uncertain.

- There are differences within countries, between urban and rural areas and according to income, education, and nationality.

significant Polish minority, which was analysed separately.

\section{Results}

Table 1 shows the sociodemographic characteristics of the sample and some characteristics of the countries.

The percentages of men who smoke daily were $53.9 \%, 56.0 \%$, and $53.2 \%$ respectively in Estonia, Latvia and Lithuania. The corresponding figures for women were $24.1 \%$, $10.9 \%$, and $7.6 \%$.

For both sexes, current smoking rates are consistently lowest in the age group 50 to 64 and highest in the age group 35 to 49 (fig 1).

The percentage of current smokers in each age group is remarkably similar for men in each of the three countries. There are slightly more men in Estonia who have never smoked than in the other two countries.

In contrast, smoking rates among women vary. They are lowest in Lithuania, slightly higher in Latvia, and highest in Estonia. In each country, approximately $80 \%$ of those in the oldest age group have never smoked. This percentage is substantially smaller in the younger age groups.

The odds ratios for the likelihood of smoking by a range of sociodemographic variables are shown in tables 2,3 , and 4 . In each country the likelihood of women smoking is typically about $50 \%$ lower in the oldest age group than in the youngest. Smoking is especially rare among older Lithuanian woman.

In all of the countries, there are no significant differences between men living in urban and rural areas. Women in Estonia are also similar in the two types of area but those living in rural areas of Lithuania and Latvia are significantly less likely to smoke than those in urban areas.

Among men, the likelihood of smoking is lower among those with higher incomes in all countries. In Estonia and Lithuania, an additional difference according to education just fails to reach significance.

In contrast, the likelihood of smoking by women seems not to be affected in any consistent manner by either education or income.

In table 5, data from the three countries have been brought together. In this comparison, the effect of age is again apparent, with the lowest 
Table 4 Percentages and adjusted odds ratios (95\% confidence intervals in parentheses) for present smoking among Lithuanian adults by a range of socioeconomic variables

\begin{tabular}{|c|c|c|c|c|}
\hline & Category & Unadjusted rates (\%) & Age adjusted & Fully adjusted \\
\hline \multirow[t]{3}{*}{ Male } & age $20-34$ & $57(51,62)$ & 1.00 & 1.00 \\
\hline & age $35-49$ & $60(55,65)$ & $1.14(0.85,1.54)$ & $1.14(0.83,1.57)$ \\
\hline & age $50-64$ & $40(34,46)$ & $0.52(0.38,0.71)$ & $0.48(0.33,0.70)$ \\
\hline \multirow[t]{3}{*}{ Nationality } & Lithuanian & $52(49,55)$ & 1.00 & 1.00 \\
\hline & Russian & $59(49,69)$ & $1.24(0.79,1.93)$ & $1.21(0.75,1.96)$ \\
\hline & Polish & $58(46,69)$ & $1.20(0.71,2.01)$ & $1.32(0.76,2.3)$ \\
\hline \multirow[t]{2}{*}{ Region } & Urban & $52(48,56)$ & 1.00 & 1.00 \\
\hline & Rural & $56(50,61)$ & $1.18(0.90,1.54)$ & $0.92(0.68,1.25)$ \\
\hline \multirow[t]{3}{*}{ Education } & Primary & $53(46,59)$ & 1.00 & 1.00 \\
\hline & Secondary & $59(53,65)$ & $0.84(0.56,1.25)$ & $0.85(0.55,1.29)$ \\
\hline & University & $50(46,55)$ & $0.61(0.43,0.88)$ & $0.70(0.48,1.03)$ \\
\hline \multirow{4}{*}{ Income } & under $\$ 47.5$ & $60(55,65)$ & 1.00 & 1.00 \\
\hline & $\$ 47.5-\$ 77.4$ & $50(44,56)$ & $0.66(0.47,0.92)$ & $0.69(0.49,0.97)$ \\
\hline & $\$ 77.5-\$ 97.4$ & $49(39,59)$ & $0.66(0.42,1.04)$ & $0.66(0.42,1.08)$ \\
\hline & $\$ 97.5+$ & $45(38,52)$ & $0.55(0.38,0.78)$ & $0.59(0.40,0.86)$ \\
\hline \multirow[t]{3}{*}{ Female } & age $20-34$ & $10(7,13)$ & 1.00 & 1.00 \\
\hline & age $35-49$ & $9(6,12)$ & $0.88(0.54,1.41)$ & $0.97(0.59,1.61)$ \\
\hline & age $50-64$ & $3(2,5)$ & $0.30(0.16,0.58)$ & $0.32(0.15,0.68)$ \\
\hline \multirow[t]{3}{*}{ Nationality } & Lithuanian & $7(6,9)$ & 1.00 & 1.00 \\
\hline & Russian & $13(6,19)$ & $1.93(0.97,3.84)$ & $1.87(0.92,3.82)$ \\
\hline & Polish & $9(1,16)$ & $1.27(0.49,3.31)$ & $1.36(0.51,3.61)$ \\
\hline \multirow{2}{*}{ Region } & Urban & $9(7,11)$ & 1.00 & 1.00 \\
\hline & Rural & $5(3,7)$ & $0.63(0.38,1.06)$ & $0.56(0.32,0.99)$ \\
\hline \multirow[t]{3}{*}{ Education } & Primary & $5(2,8)$ & 1.00 & 1.00 \\
\hline & Secondary & $12(8,16)$ & $1.14(0.51,2.55)$ & $1.00(0.44,2.26)$ \\
\hline & University & $6(5,8)$ & $0.60(0.27,1.31)$ & $0.58(0.26,1.29)$ \\
\hline \multirow[t]{4}{*}{ Income } & under $\$ 47.5$ & $10(7,13)$ & 1.00 & 1.00 \\
\hline & $\$ 47.5-\$ 77.4$ & $4(2,6)$ & $0.45(0.24,0.82)$ & $0.41(0.22,0.76)$ \\
\hline & $\$ 77.5-\$ 97.4$ & $7(3,12)$ & $0.73(0.35,1.50)$ & $0.68(0.32,1.44)$ \\
\hline & $\$ 97.5+$ & $8(4,11)$ & $0.67(0.37,1.22)$ & $0.66(0.35,1.23)$ \\
\hline
\end{tabular}

probability of smoking for both sexes but especially women in the oldest age group. Among men, differences by nationality are, in general, not significant, except for the higher figure for Russians. This remains after adjustment for urban/rural residence, income and education. As table 3 shows, this difference only reaches significance in Latvia, although the values

Table 5 Adjusted odds ratios (95\% confidence intervals in parentheses) for present smoking among adults from the three Baltic Republics combined by a range of socioeconomic variables

\begin{tabular}{|c|c|c|c|}
\hline & & Fully adjusted & Age adjusted \\
\hline \multirow[t]{3}{*}{ Male } & age $19-34$ & 1.00 & 1.00 \\
\hline & age $35-49$ & $1.28(1.07,1.53)$ & $1.33(1.12,1.58)$ \\
\hline & age $50-64$ & $0.56(0.46, .69)$ & $0.62(0.52,0.75)$ \\
\hline \multirow{6}{*}{ Nationality } & Lithuanian & 1.00 & 1.00 \\
\hline & Latvian & $1.00(0.8,1.26)$ & $1.01(0.91,1.40)$ \\
\hline & Estonian & $1.07(0.86,1.34)$ & $0.99(0.80,1.22)$ \\
\hline & Russian & $1.46(1.17,1.83)$ & $1.45(1.18,1.80)$ \\
\hline & Polish & $1.32(0.76,2.3)$ & $1.20(0.72,2.00)$ \\
\hline & Other & $0.97(0.69,1.38)$ & $1.01(0.72,1.41)$ \\
\hline \multirow{2}{*}{ Region } & Urban & 1.00 & 1.00 \\
\hline & Rural & $0.93(0.79,1.1)$ & $1.04(0.89,1.21)$ \\
\hline \multirow{3}{*}{ Education } & Primary & 1.00 & 1.00 \\
\hline & Secondary & $0.87(0.69,1.1)$ & $0.85(0.68,1.06)$ \\
\hline & University & $0.74(0.59, .92)$ & $0.67(0.54,0.82)$ \\
\hline \multirow[t]{4}{*}{ Income } & Lowest & 1.00 & 1.00 \\
\hline & 2 & $0.72(0.59, .87)$ & $0.71(0.59,0.85)$ \\
\hline & 3 & $0.69(0.54, .87)$ & $0.68(0.54,0.85)$ \\
\hline & Highest & $0.55(0.43, .71)$ & $0.52(0.41,0.66)$ \\
\hline \multirow[t]{3}{*}{ Female } & age $19-34$ & 1.00 & 1.00 \\
\hline & age $35-49$ & $1.09(0.87,1.37)$ & $0.99(1.12,1.58)$ \\
\hline & age $50-64$ & $0.43(0.32, .57)$ & $0.38(0.52,0.75)$ \\
\hline \multirow[t]{6}{*}{ Nationality } & Lithuanian & 1.00 & 1.00 \\
\hline & Latvian & $1.61(1.11,2.34)$ & $1.48(1.04,2.12)$ \\
\hline & Estonian & $4.12(3.01,5.64)$ & $4.04(3.00,5.43)$ \\
\hline & Russian & $2.64(1.91,3.64)$ & $2.71(1.99,3.67)$ \\
\hline & Polish & $1.38(0.53,3.61)$ & $1.27(0.49,3.30)$ \\
\hline & Other & $2.61(1.63,4.17)$ & $2.63(1.67,4.14)$ \\
\hline \multirow[t]{2}{*}{ Region } & Urban & 1.00 & 1.00 \\
\hline & Rural & $0.70(0.55, .89)$ & $0.70(0.56,0.87)$ \\
\hline \multirow{3}{*}{ Education } & Primary & 1.00 & 1.00 \\
\hline & Secondary & $1.16(0.81,1.65)$ & $1.44(1.02,2.03)$ \\
\hline & University & $0.76(0.53,1.09)$ & $0.86(0.61,1.21)$ \\
\hline \multirow[t]{4}{*}{ Income } & Lowest & 1.00 & 1.00 \\
\hline & 2 & $0.75(0.59, .96)$ & $0.89(0.71,1.12)$ \\
\hline & 3 & $0.94(0.69,1.28)$ & $1.18(0.89,1.56)$ \\
\hline & Highest & $1.05(0.72,1.52)$ & $0.86(0.61,1.22)$ \\
\hline
\end{tabular}

Table 6 Odds ratio of quitting in Lithuania

\begin{tabular}{lll}
\hline & & $\begin{array}{l}\text { Odds ratio } \\
\text { (95\% confidence intervals) }\end{array}$ \\
\hline Male & age 19-34 & 1.00 \\
& age 35-49 & $1.63(0.89,2.96)$ \\
Nationality & age 50-64 & $6.73(3.65,12.42)$ \\
& Lithuanian & 1.00 \\
Region & Russian & $1.01(0.58,1.77)$ \\
& Urban & 1.00 \\
Education & Rural & $0.95(0.59,1.52)$ \\
& Primary & 1.00 \\
Income & Secondary & $1.20(0.63,2.32)$ \\
& University & $1.48(0.83,2.66)$ \\
& Lowest & 1.00 \\
Female & 2 & $1.48(0.86,2.52)$ \\
& 3 & $0.98(0.44,2.18)$ \\
Nationality & Highest & $1.38(0.74,2.55)$ \\
& age 19-34 & 1.00 \\
Region & age 35-49 & $0.49(0.24,1.02)$ \\
& age 50-64 & $0.51(0.19,1.37)$ \\
Education & Rithuanian & 1.00 \\
& Russian & $0.46(0.19,1.11)$ \\
Unban & 1.00 \\
& Rural & $1.31(0.61,2.81)$ \\
& Primary & 1.00 \\
& Secondary & $1.72(0.48,6.12)$ \\
& University & $3.29(0.96,11.24)$ \\
& Lowest & 1.00 \\
& 2 & $1.98(0.83,4.74)$ \\
& 3 & $1.64(0.61,4.39)$ \\
& Highest & $1.32(0.57,3.06)$ \\
& &
\end{tabular}

obtained from the other countries are suggestive of this difference.

Among women there is a clear gradation by nationality, with the lowest probability among Lithuanians, followed by Latvians, Russians and then Estonians. Again, this difference remains after adjustment for the remaining variables. The previously noted association with income, among men, is confirmed, but here education seems to have an independent effect. Men with university education are also less likely to smoke but for women the difference is not significant.

A further analysis was undertaken to examine the high rate of quitting in Lithuania, by selecting all those who had ever smoked and examining the variables associated with successful quitting (table 6). The model was adjusted for all variables. Unfortunately the numbers were relatively small, making it difficult to detect significant differences. The only variable that was significant was age, with a higher probability of quitting among the oldest group of men, although there was also a suggestion of an association with education.

\section{Discussion}

Before discussing the results, the limitations of the survey must be considered. Although the overall sample was relatively large, the small size of certain groups, reduced the power to detect significant differences. Furthermore, data were only collected for those between the ages of 19 (20 in Lithuania) and 64 so we do not have data for the elderly or for teenagers. A further limitation is the absence of independent validation of self reported smoking behaviour, such as measures of cotinine.

With these caveats, however, this survey provides important new information on the socioeconomic determinants of smoking among the populations of the three countries.

In each country, smoking rates among men are relatively homogeneous. In particular there 
Table 7 Elements of anti-smoking strategies adopted in the Baltic Republics

\begin{tabular}{|c|c|c|c|}
\hline Element & Estonia & Latvia & Lithuania \\
\hline $\begin{array}{l}\text { Preventing addiction } \\
\text { among children }\end{array}$ & $\begin{array}{l}\text { It is illegal to sell cigarettes near schools or to } \\
\text { persons under } 16 \text { years old but this is not } \\
\text { enforced. }\end{array}$ & $\begin{array}{l}\text { It is illegal to sell cigarettes near schools } \\
\text { or to persons under } 18 \text { years old but this } \\
\text { is not enforced. Illegal to sell tobacco at } \\
\text { health, education and sports facilities and } \\
\text { from machines. }\end{array}$ & $\begin{array}{l}\text { It is illegal to sell cigarettes near schools or to } \\
\text { persons under } 18 \text { years old but this is not } \\
\text { enforced. }\end{array}$ \\
\hline $\begin{array}{l}\text { Preventing involuntary } \\
\text { exposure to smoke }\end{array}$ & $\begin{array}{l}\text { Smoking banned in health care, educational } \\
\text { and government facilities and in public } \\
\text { transport but weakly enforced. }\end{array}$ & $\begin{array}{l}\text { Smoking banned in health care, facilities, } \\
\text { working places, in theatres, cinemas and } \\
\text { other public buildings, in public } \\
\text { transportation, except special smoking } \\
\text { places. Employers must create } \\
\text { tobacco-free areas for non-smokers. }\end{array}$ & $\begin{array}{l}\text { Smoking banned in indoor public places and } \\
\text { transport, although these have been } \\
\text { traditionally smoke-free (except taxis). } \\
\text { Smoking in public by uniformed public } \\
\text { employees banned. Places where food is } \\
\text { served must have non-smoking provision. }\end{array}$ \\
\hline $\begin{array}{l}\text { Providing effective } \\
\text { programmes of } \\
\text { health promotion } \\
\text { and education }\end{array}$ & $\begin{array}{l}\text { From } 1995 \text { the Health Insurance Fund } \\
\text { contributed } 0.5-1 \% \text { of revenue for health } \\
\text { promotion projects, open to tender. This led } \\
\text { to the promotion of an increased number of } \\
\text { public health specialists, many of whom have } \\
\text { initiated action on tobacco. }\end{array}$ & $\begin{array}{l}\text { Some programmes exist but are not } \\
\text { widespread. }\end{array}$ & $\begin{array}{l}\text { Kaunas participates in the WHO Multi-City } \\
\text { Action Plan and is a WHO Healthy City. } \\
\text { Lithuania participates actively in the CINDI } \\
\text { Programme. }\end{array}$ \\
\hline $\begin{array}{l}\text { Effective smoking } \\
\text { cessation } \\
\text { programmes }\end{array}$ & $\begin{array}{l}\text { Since } 1995 \text { an anti-smoking project has been } \\
\text { undertaken annually, including the Quit and } \\
\text { Win programme. This includes training for } \\
\text { professionals. An additional project aimed at } \\
\text { young people was initiated in } 1996 \text {. The } \\
\text { Cancer Union provides a counselling help } \\
\text { line for those wishing to quit. }\end{array}$ & $\begin{array}{l}\text { Some programmes exist but are not } \\
\text { widespread. }\end{array}$ & Various small scale projects exist. \\
\hline $\begin{array}{l}\text { Prominent health } \\
\text { warnings }\end{array}$ & $\begin{array}{l}\text { Health warning required on packets of } \\
\text { domestically produced cigarettes. }\end{array}$ & $\begin{array}{l}\text { The message 'Smoking is very bad for } \\
\text { your health' must appear on one side of } \\
\text { each packet but its size is not defined. } \\
\text { Health warning required at point of sale. }\end{array}$ & Health warning on packets. \\
\hline $\begin{array}{l}\text { Elimination of } \\
\text { advertising }\end{array}$ & $\begin{array}{l}\text { Television and radio advertising banned. } \\
\text { Billboard advertising is controlled by county } \\
\text { councils and some have banned advertising } \\
\text { of tobacco. }\end{array}$ & $\begin{array}{l}\text { Television, radio, billboard and press } \\
\text { advertising banned. }\end{array}$ & $\begin{array}{l}\text { Television, radio, billboard, press and cinema } \\
\text { and indirect advertising (such as on bags, } \\
\text { umbrellas, etc) banned but ban on indirect } \\
\text { advertising widely ignored. Sponsorship of } \\
\text { events aimed at under } 18 \mathrm{~s} \text { is banned. }\end{array}$ \\
\hline Financial measures & Tax at $70 \%$ of retail price. & $\begin{array}{l}\text { Tobacco is subject to a hypothecated tax } \\
\text { that is used to support the health budget. } \\
\text { Prices have not, however, risen in line } \\
\text { with inflation. }\end{array}$ & $\begin{array}{l}\text { Tax at } 36 \% \text { of retail price. Prices are low } \\
\text { compared with neighbouring countries, such } \\
\text { as Poland, so smuggling is extensive. }\end{array}$ \\
\hline
\end{tabular}

is little urban-rural difference. Smoking rates are, however, rather less frequent among the wealthy. Looking at the nationalities together, rates are relatively similar, except for Russians. The reasons for the higher smoking rates among Russians must remain speculative, except that these data show that they cannot be attributable solely to educational and income differences. The rates among Russian men are comparable to those in a similar survey undertaken in Russia, where levels are fairly consistent throughout the country. ${ }^{4 a}$ Among women in Russia, rates are much more variable, as is the case in the Baltic Republics. Although there is a considerable literature on health behaviour of migrants that could inform this discussion, it is not clear how well it applies to a situation such as this. The context of the original movements of population differs considerably from, for example, the more intensively studied migrants from Asia or Europe to America.

There is much more diversity among women, with the highest rates among Estonians and a clear urban-rural split, except in Estonia. Unlike men, rates do not decrease with increasing education. The finding can be interpreted as showing higher rates of smoking in those who have been most exposed to western influences. For example, Estonian women have long had access to Finnish television programmes. With the exception of lower rates among those aged over 50, smoking rates are relatively homogeneous within Estonia. The absence of an urban-rural gradient in Estonia seems likely to be because the rural areas in Estonia are much less "rural" than in the other countries. In Estonia, a much lower percentage of the population is employed in agriculture and many of those living in "rural" areas work in towns and cities. Thus a higher proportion of the population in Estonia is likely to be exposed to predominantly urban tobacco advertising.

The other countries display much greater diversity. In them, smoking rates are consistently higher in urban than in rural areas. Unlike the situation with men, income seems to have little effect on smoking behaviour.

The overall figures are broadly in line with previously published data, with the exception of the results for Lithuanian women, where we have produced a lower estimate than that in the WHO database. We are unable to explain this difference but it is conceivable that there has been a difference in the sampling frames.

This study offers a baseline for future monitoring but it is also possible, with caution, to say something about trends on the basis of health behaviour surveys conducted since independence, with support from Finnish researchers. ${ }^{56} \mathrm{~A}$ survey conducted with the same age range in 1994 found rates of smoking in Lithuania of $43.3 \%$ among men and $6.3 \%$ among women, ${ }^{7}$ figures that are slightly lower than in this study. Data are also available from Estonia for 1990, 1994, and $1996 .{ }^{8}$ These indicate an upward trend among women, with rates of $15 \%, 25 \%$, and $22 \%$ respectively. Rates among men are more stable at $45 \%, 52 \%$, and $43 \%$ respectively.

Each country has recently introduced legislation to reduce smoking, ${ }^{910}$ although the effects would not be expected to be apparent in these data. 
In Latvia an act on The production, distribution and sale, and advertising of tobacco products, and the control of smoking was enacted in December 1996. In Lithuania, a tobacco control act was also adopted in 1996. In Estonia, an act is with parliament at the time of writing (July 1998).

Details of the elements of a comprehensive anti-smoking strategy adopted are listed in table $7 .^{10}$ In Latvia, action against smoking is largely undertaken by institutes under the auspices of the Ministry of Welfare. In Estonia, the medical association has been especially active. In Lithuania, there is an especially active nongovernmental sector, with involvement by public health professionals, especially in the Kaunas Medical Academy. The staff of the academy have been actively involved in international collaborative programmes, such as the WHO CINDI Programme, for many years and Lithuania was the first country in the Baltics to host a WHO Healthy City. This would seem to have been especially effective as the percentage of ex-smokers is generally higher in Lithuania than in the other countries. This is especially noticeable among young women.

One problem should be noted. While each country prohibits tobacco advertising on television and radio, it is not possible to control the widespread tobacco advertising on television from neighbouring Russia.

While much more needs to be done to develop policies, further implementation of effective and comprehensive anti-smoking policies is also needed. Each country is at the beginning of stage III of the cigarette epidemic, as defined by Lopez et $a l,{ }^{11}$ and while robust action would have been helpful somewhat earlier, sustained efforts now will make a difference in the future.

This survey has indicated the scale of the problem but, as well as action, what is now needed is detailed qualitative research to understand why different groups smoke and which messages would be most effective in persuading them to stop or, preferably, preventing the onset of smoking. In particular, there is a strong case for examining the reasons behind the apparent increase in smoking among women in Estonia as this may indicate future trends in the other countries. It is also important to understand better the reasons for the apparently greater success in helping people quit in Lithuania, information that would build on research from elsewhere about the strategies that are most effective in promoting cessation. ${ }^{12}$

We are grateful to the following who assisted with organisation of the surveys: Roma Bartkeviciute, $\mathrm{MD}, \mathrm{PhD}$, Head of Department of National Nutrition Centre, Kalvariju str 153, 2042, Vilnius, Lithuania; Dr Mary Serdula, Department of Nutrition, CDC, Atlanta, USA; Dr Ritva Prõttala, Institute of Public Health, Helsinki, Finland; Mr Eric Poortvliet, Unit for Preventive Nutrition, Novum, 14151 Huddinge, Sweden.

Funding: the surveys were funded by the Ministry of Foreign Affairs, Luxembourg and WHO and the work of ECOHOST is Affairs, Luxembourg and WHO and the work of ECOHOST is
supported by the UK Department for International Developsupported by the UK Department for International Develop-
ment. However neither DfID, the Government of Luxembourg ment. However neither DfID, the Government of Luxembourg
nor WHO can accept any responsibility for any information nor WHO can accept any rest
provided or views expressed.

Conflicts of interest: none.

1 Puska P. Smoking in central and eastern Europe. In: Waller M, Lipponen S. Smoke free Europe: A forum for networks. Helsinki: Finnish Centre for Health Promotion, 1996:13845 .

2 Peto R, Lopez AD, Boreham J, et al. Mortality from smoking in developed countries 1950-2000. Oxford: Oxford University Press, 1994.

3 Kubik AK, Parkin DM, Plesko I, et al. Patterns of cigarette sales and lung cancer mortality in some central and eastern European countries, 1960-1989. Cancer 1995;75: 245260.

4 WHO. Health for All database. Copenhagen: WHO, 1998.

4a McKee M, Bobak M, Rose R, et al. Patterns of smoking in Russia. Tobacco Control 1998; 7:22-6.

5 Puska P. Health promotion challenges for countries of the former Soviet Union: results from collaboration between Estonia, Russian Karelia and Finland. Health Promotion 1995;10:219-28.

6 Anon. FinnBalt Health Monitor. A collaborative system for monitoring health-related behaviour, practices and lifestyles in Estonia, Finland, Latvia and Lithuania. Helsinki: Finnish National Public health Institute, undated.

7 Graubaskas V, Klumbiene J, Petkeviciene J, et al. Suaugusiu lietuvos zmoniu gyvensensos tyrimas, 1994. Kaunas/ Helsinki: Kaunas Medical Academy/ National Public Health Institute, Finland, 1997.

8 Anon. Eeesti taiskasvanud elanikkenna terviskaitymiseuuring kevad 1996. Tallinn: National Public Health Institute, 1997.

9 WHO. Tobacco or health: a global status report. Geneva: WHO, 1997:299-301, 340-5.

10 Harkin AM, Anderson P, Goos C. Smoking, drinking and drug taking in the European Region. Copenhagen: WHO, 1997.

11 Lopez A, Collishaw NE, Piha T. A descriptive model of the cigarette epidemic in developed countries. Tobacco Control 1994;3:242-7.

12 Korhonen T, Su S, Korhonen HJ, et al. Evaluation of a national Quit and Win contest: determinants for successful quitting. Prev Med 1997;26:556-4. 